\title{
Stability Indicating Assay Method Development and Validation for Simultaneous Estimation of Ofloxacin and Ornidazole by RP-HPLC in Bulk: An Application to Tablet Formulation and Dissolution Studies
}

\author{
Kevita D’Souza, Alisha Syeda, Parnika Khatal, Muddukrishna Badamane Sathyanarayana, \\ Vasantharaju SG*
}

Department of Pharmaceutical Quality Assurance, Manipal College of Pharmaceutical Sciences, Manipal-Udupi, Karnataka, INDIA.

\begin{abstract}
Aim: The present article focuses on development of sensitive, simple, precise, accurate and inexpensive stability indicating assay method for the simultaneous estimation of Ofloxacin and Ornidazole in bulk was established using RP-HPLC. Materials and Methods: The separation was done with $\mathrm{C}_{18}$ Phenomenex Hyperclone BDS column $(250 \times 4.6 \mathrm{~mm}, 5 \mu)$ at a temperature of $25^{\circ} \mathrm{C}$ using a mobile phase of acetonitrile: $\mathrm{pH} 5.8$ ammonium acetate buffer of ratio $25: 75$ with a flow rate of $1 \mathrm{ml} / \mathrm{min}$. The detection was done at $293 \mathrm{~nm}$ and $311 \mathrm{~nm}$ and the retention time for Ofloxacin and Ornidazole was $4.278 \mathrm{~min}$ and $6.750 \mathrm{~m}$ respectively. Results: The method was seen to be linear over the range of $2-16 \mu \mathrm{g} / \mathrm{ml}$ for both drugs. The method was precise and robust with LOD of 0.331 and 0.360 and LOQ of $1.005 \mu \mathrm{g} / \mathrm{ml}$ and $1.092 \mu \mathrm{g} / \mathrm{ml}$ for Ofloxacin and Ornidazole respectively. The drugs were subjected to stress conditions in acidic, alkaline, oxidative, thermal and photolytic conditions. Conclusion: The method for this simultaneous estimation was found to be accurate, precise, fast and simple with a run time within $8 \mathrm{~min}$. This method developed was applied with success for the assay and dissolution studies in tablet formulation.
\end{abstract}

Key words: Ofloxacin, Ornidazole, Stability indicating method, HPLC, Dissolution.

\section{INTRODUCTION}

Ofloxacin (7-fluoro-2-methyl-6(4-methylpiperazin-1-yl)-10-oxo$4-$ oxa- 1 azatricyclo [7.3.1.0 5, 13] trideca-5(13),6,8,11-tetraene-11-carboxylic acid; hydrochloride) falls under a class of antibiotics named Quinolone antibiotics (Figure 1). It is deemed to be very versatile in terms of infections originating from bacteria mainly infections of the skin, lungs, bladder and kidneys, or prostrate by impairing the bacterial growth by suppressing the enzymes mostly responsible for actions such as of transcription, repair, recombination and replication of DNA gyrase and bacterial topoisomerase IV (belonging to the class of type II topoisomerases). It is reported officially in the United States Pharmacopoeia, British Pharmacopoeia and Indian Pharmacopoeia. Ornidazole (1-chloro-3-(2-methyl-5-nitroimidazol1-yl)propan-2-ol) has been derived from 5-nitroimidazole (Figure 1) and is effective in attacking anaerobic bacteria and protozoa. This is transformed into reduction products that bind with DNA causing degradation of both the framework and strand of helical DNA, leading to protein synthesis inhibition and apoptosis in vulnerable organisms. It is official in Indian Pharmacopoeia. B. Dhandapani and N. Thirumoorthy 2010. ${ }^{1}$ Developed a RP-HPLC method to quantify ofloxacin and ornidazole in tablet formulation. Nooman A. Khalaf, Ashok K. Shakya and Maher Shurabji 2010. ${ }^{2}$ Developed a RP-HPLC method to quantify ofloxacin
Submission Date: 22-07-2020; Revision Date: 22-12-2020; Accepted Date: 01-03-2021

DOI: 10.5530/ijper.55.2.100 Correspondence: Dr. Vasantharaju SG Department of Pharmaceutical Quality Assurance, Manipal College of Pharmaceutical Sciences, Manipal-Udupi, Karnataka576 104, INDIA. Phone no: +919880106983 Email id: sgvasanth65@ gmail.com

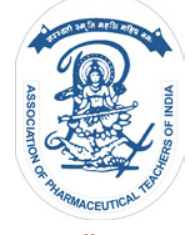

www.ijper.org 

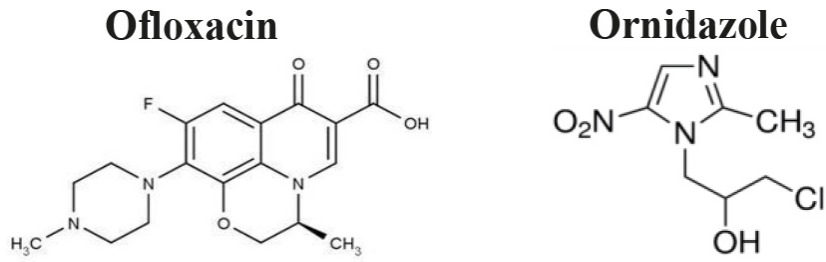

Figure 1: Structures of Ofloxacin and Ornidazole.

and ornidzole in tablet formulation. Shaik Mohammed Yusuf, E. Vijay Kumar, C. Surya Svarny and E. Divya. ${ }^{3}$ Developed a new RP-HPLC method for the simultaneous estimation of Ornidazole and Ofloxacin in its bulk and tablet dosage form. Bhusari KD and Chaple DR 2009. ${ }^{4}$ Developed a spectrophotometric method for the simultaneous estimation in tablet dosage form of ofloxacin and ornidazole. Saumil Mehta and Sukhdev Singh. ${ }^{5}$ Developed a spectrophotometric method for the simultaneous estimation in combined dosage form of ofloxacin and ornidazole using UV spectrophotometer. The Indian Pharmacopoeia, Volume III 2018.6 was referred for the dissolution procedure.

Literature study showed that analytical techniques vir: HPTLC and HPLC methods have been presented for simultaneous determination of ofloxacin and ornidazole. There is no article related to Stability Indicating HPLC method to quantify Ofloxacin and Ornidazole in bulk has ever been mentioned within literature referred. The primary goal of this study was to produce a specific, accurate and reproducible stability indicating HPLC method for estimation of Ofloxacin (OFL) and Ornidazole $(\mathrm{ORN})$ as stated in the $\mathrm{ICH}$ guidelines.

\section{MATERIALS AND METHODS}

\section{Chemicals and reagents}

All chemicals were of analytical grade. Ofloxacin and Ornidazole working standards were obtained as gift samples from AKUMS Drugs and Pharmaceuticals Ltd (Haridwar, India). Methanol (HPLC grade) and potassium hydroxide (analytical grade) were bought from Finar Limited (Mumbai, India), triethylamine (HPLC grade) and acetonitrile (HPLC grade) were bought from Spectrochem Pvt. Ltd. (Mumbai, India) and potassium dihydrogen phosphate (analytical grade) and ammonium acetate (analytical grade) was bought from Lobachem (Mumbai, India). The tablet formulation was (Oflox Oz, Cipla Ltd., Sikkim, India) containing 200mg of ofloxacin and $500 \mathrm{mg}$ of ornidazole was obtained locally and thus used for the analysis of the marketed formulation.

\section{Instrumentation}

The liquid chromatographic system used was Shimadzu LC20 AD (Shimadzu, Kyoto, Japan) equipped with gradient pump, auto- injector, photo diode array detector and also UV-Vis detector. LC solution software on a $\mathrm{C}_{18}$ Phenomenex Monomeric 130A $(250 \times 4.6 \mathrm{~mm}, 5 \mu \mathrm{m})$ was utilised to carry out the chromatographic analysis. Dissolution system used was Electrolab dissolution tester (USP) TDT-08L.

\section{Preparation of Buffer}

$10 \mathrm{mM}$ ammonium acetate buffer $(\mathrm{pH} 5.8 \pm 0.02)$ : $0.77 \mathrm{~g}$ of ammonium acetate was dissolved in $1000 \mathrm{ml}$ of milli-Q water and $\mathrm{pH}$ adjusted to $5.8 \pm 0.02$ using potassium hydroxide solution. A $0.45 \mu$ filter using vacuum filtration was used to filter the resulting solution and the solution was then subjected to sonication for $15 \mathrm{~min}$.

\section{Preparation of Stock solution}

The stock solution was made by weighing $10 \mathrm{mg}$ each of ofloxacin and ornidazole working standard accurately and separately into two $10 \mathrm{ml}$ volumetric flasks. They were then dissolved in methanol and the resulting solutions were sonicated and volume made upto the mark using methanol to acquire a solution of $1000 \mu \mathrm{g} / \mathrm{ml}$ of each drug. $1 \mathrm{ml}$ was withdrawn from each standard stock solution, shifted into separate $10 \mathrm{ml}$ volumetric flask and the final volume was made up to the mark using methanol $(100 \mu \mathrm{g} / \mathrm{ml}$ - Stock solution A). $0.8 \mathrm{ml}$ was withdrawn from each stock solution A into separate $10 \mathrm{ml}$ volumetric flask and the final volume was made up to the mark using the mobile phase $(8 \mu \mathrm{g} / \mathrm{ml}$-ofloxacin and ornidazole.)

A reversed- phase high- performance liquid chromatographic system using isocratic elution mode with a mobile phase of acetonitrile: $10 \mathrm{mM}$ ammonium acetate buffer, with the $\mathrm{pH}$ adjusted to 5.8 with potassium hydroxide $(25: 75 \mathrm{v} / \mathrm{v})$ with the addition of $1 \%$ trieethylamine to the aqueous phase and 10\% methanol to the organic phase on $\mathrm{C}_{18}$ Phenomenex Monomeric $130 \mathrm{~A}(250 \times 4.6 \mathrm{~mm}, 5 \mu \mathrm{m})$ with $1 \mathrm{ml} / \mathrm{min}$ flow rate at $295 \mathrm{~nm}$ and $311 \mathrm{~nm}$ with PDA and UV-Vis detector was used to carry out the HPLC analysis.

\section{Calibration curves for OFL and ORN}

Tablet formulation contains OFL: ORN in ratio of 2:5. Required aliquots of OFL and ORN stock solutions were transferred in $10 \mathrm{ml}$ volumetric flask and diluted up to the mark using the mobile phase for concentrations of $2-16 \mu \mathrm{g} / \mathrm{ml}$ for both ofloxacin and ornidazole. The volume solutions injected were $20 \mu \mathrm{l}$ and chromatograms were aptly recorded. A computation of regression equations was done for both the drugs and average peak 
Table 1: Linear Regression data for Calibration curves.

\begin{tabular}{|c|c|c|}
\hline \multicolumn{2}{|c|}{ Curves. } \\
\hline Parameters & Ofloxacin & Ornidazole \\
\hline Range of Linearity $(\mu \mathrm{g} / \mathrm{ml})$ & $2-16$ & $2-16$ \\
\hline Correlation coefficient & 0.9993 & 0.9991 \\
\hline Slope & 95462 & 50655 \\
\hline y- intercept & 32202 & 18861 \\
\hline
\end{tabular}

areas versus concentrations were plotted to construct calibration curves (Table 1).

\section{Marketed Formulation Analysis}

Twenty tablets were weighed and their average weight was calculated. The same tablets were then powdered and transferred into a $100 \mathrm{ml}$ volumetric flask with a weight equivalent to $20 \mathrm{mg}$ of ofloxacin. Then the powder was dissolved using methanol and the solution obtained was subjected to sonication and volume made upto the mark using methanol to gain a concentration of $200 \mu \mathrm{g} / \mathrm{ml}$ of ofloxacin. The solution was filtered via a $0.45 \mu$ filter using vacuum filtration. $1 \mathrm{ml}$ from the above solution was withdrawn and displaced into a $10 \mathrm{ml}$ volumetric flask; volume was made up using mobile phase. $1 \mathrm{ml}$ from the above solution was withdrawn and displaced to $10 \mathrm{ml}$ volumetric flask; volume was made up with the help of

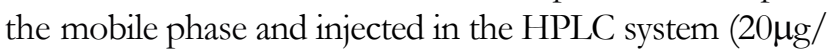
$\mathrm{ml} \mathrm{OFL}$ and $50 \mu \mathrm{g} / \mathrm{ml} \mathrm{ORN})$. A volume of $20 \mu \mathrm{l}$ of the solution obtained above was injected into the HPLC system and the areas of the peaks obtained under the optimized chromatographic conditions were measured.

\section{Method Validation}

The analytical approach was validated for the parameters such as accuracy, linearity, precision, detection limit, quantization limit and robustness as per the recommendations of ICH Q2 (R1). The method's accuracy was estimated by measuring OFL and ORN's percentage recovery. The recovery studies were conducted by utilizing the same method for the drug sample to which documented amounts of OFL and ORN equivalent to 80,100 and 120 percent of the label claim had been inserted (standard addition method). Three determinations were carried out at each level of the amount and the obtained results were then compared.

Intraday and inter day OFL and ORN precision analysis was conducted by calculating the related responses three times at different time intervals on the same day and on three separate days for a sample containing $8 \mu \mathrm{g} / \mathrm{ml}$ of OFL and ORN. The limit of detection (LOD) and limit of quantitation (LOQ) were estimated by utilizing the given formulae: $\mathrm{LOD}=3.3(\mathrm{SD}) / \mathrm{S}$ and $\mathrm{LOQ}=10(\mathrm{SD}) / \mathrm{S}$, where $\mathrm{SD}=$ standard deviation of response (peak area) and $S=$ average of the slope of the calibration curve.

System suitability testing is a vital part of the chromatographic method and is useful in verifying the chromatographic system reproducibility. To assess its efficacy, some system suitability test parameters have been tested by repeated injections of the solution containing drug sample at the concentration of $8 \mu \mathrm{g} / \mathrm{ml}$ OFL and ORN to verify the system's reproducibility and the results are shown in Table 2.

A few parameters such as column oven temperature, wavelength, flow rate and $\mathrm{pH}$ of mobile phase were purposefully changed for the evaluation of robustness of the HPLC method. At one time, one factor was modified for estimating the effect. With respect to optimized parameters, each factor was assessed at three different levels $(-2,0,+2)$. Method robustness was conducted at the concentration level of $8 \mu \mathrm{g} / \mathrm{ml}$ for both OFL and ORN.

\section{Forced degradation studies}

Forced degradation studies of bulk and tablet formulation were performed under acid and alkali hydrolysis, thermal, oxidative and photolytic degradation. Forced degradation in acid media was carried out by weighing $10 \mathrm{mg}$ of OFL and ORN in first $50 \mathrm{ml}$ round bottom flask with the addition of $50 \mathrm{ml}$ of $0.1 \mathrm{M}$ hydrochloric. These mixtures were administered to room temperature for $8 \mathrm{hrs}$. Similarly, forced degradation in alkali media was carried out by adding $50 \mathrm{ml}$ of $0.1 \mathrm{M}$ sodium hydroxide and kept for 8

\begin{tabular}{|c|c|c|}
\hline \multicolumn{3}{|c|}{$\begin{array}{c}\text { Table 2: Summary of System suitability and } \\
\text { Validation Parameters. }\end{array}$} \\
\hline Parameters & Ofloxacin & Ornidazole \\
\hline $\begin{array}{l}\text { Retention time } \pm \text { allowable time } \\
(\mathrm{m})\end{array}$ & $4.28 \pm 0.03$ & $6.75 \pm 0.3$ \\
\hline Theoretical Plates & 4852.55 & 7829.49 \\
\hline Tailing factor (asymmetry factor) & 1.55 & 1.08 \\
\hline $\begin{array}{l}\text { Range of Linearity } \\
(\mu \mathrm{g} / \mathrm{ml})\end{array}$ & $2-16$ & $2-16$ \\
\hline Correlation coefficient & 0.9993 & 0.9991 \\
\hline $\begin{array}{l}\mathrm{LOD} \\
(\mu \mathrm{g} / \mathrm{ml})\end{array}$ & 0.331 & 0.36 \\
\hline $\begin{array}{l}\mathrm{LOQ} \\
(\mu \mathrm{g} / \mathrm{ml})\end{array}$ & 1.005 & 1.092 \\
\hline $\begin{array}{c}\text { Recovery } \\
(\%)\end{array}$ & 101.37 & 100.52 \\
\hline \multicolumn{3}{|l|}{$\begin{array}{l}\text { Precision } \\
\text { (\%RSD) }\end{array}$} \\
\hline Inter-day $(n=6)$ & 0.38 & 0.52 \\
\hline Intra-day $(n=6)$ & 0.18 & 0.33 \\
\hline Robustness & Robust & Robust \\
\hline
\end{tabular}


hrs at room temperature. This procedure was repeated but this time by refluxing all the above solutions except for ornidazole in $0.1 \mathrm{M}$ sodium hydroxide. Degradation using hydrogen peroxide was carried out by weighing $10 \mathrm{mg}$ of OFL and ORN in separate $10 \mathrm{ml}$ volumetric flasks and volume was made up using methanol. From each, $1 \mathrm{ml}$ was displaced into a $10 \mathrm{ml}$ volumetric flask and volume was made up using $30 \% \mathrm{v} / \mathrm{v}$ hydrogen peroxide solution $(100 \mu \mathrm{g} / \mathrm{ml})$ for bulk drugs. These mixtures were administered to room temperature for $4 \mathrm{hrs}$. For thermal and photolytic degradations, bulk drugs were placed in a petri dish in an oven for $24 \mathrm{hr}$ at $80^{\circ} \mathrm{C}$ and in direct sunlight for $4 \mathrm{hr}$, respectively.

All the obtained degraded samples solutions were then diluted using the mobile phase to gain a final concentration of $10 \mu \mathrm{g} / \mathrm{ml}$ OFL and ORN for HPLC analysis. Following that, $20 \mu$ solution from the solutions obtained above were inserted into the HPLC system and examined using the previously mentioned chromatographic conditions.

\section{Dissolution studies}

The dissolution studies of Ofloxacin and Ornidazole fixed dose combination tablet was performed. For the dissolution procedure the Dissolution media was $900 \mathrm{~mL} 0.1 \mathrm{~N}$ HCL prepared by diluting $8.25 \mathrm{ml}$ of $37.5 \%$ HCL to $1000 \mathrm{ml}$ with water. The Dissolution apparatus used was IP Apparatus 1 (Paddle Apparatus) with a temperature of $37 \pm 5^{\circ} \mathrm{C}$ at a stirring speed of $50 \mathrm{rpm}$ and at time intervals of $0,10,20,30,45,60$ min. Dissolution testing was performed at the above conditions for 6 different tablets in the dissolution media by withdrawing $5 \mathrm{ml}$ of the solution each time and replacing with $5 \mathrm{ml}$ of dissolution media and the percentage of the dissolved drug was estimated and the cumulative percentage of drug dissolved with time was plotted.

\section{RESULTS AND DISCUSSION}

The mobile phase consists of acetonitrile: $10 \mathrm{mM}$ ammonium acetate buffer, whose $\mathrm{pH}$ is adjusted to 5.8 with potassium hydroxide $(30: 70 \mathrm{v} / \mathrm{v})$ along with the addition of $1 \%$ TEA to the aqueous phase and $10 \%$ methanol to the organic phase, at $1 \mathrm{ml} / \mathrm{min}$ flow rate was optimized and it resulted in well-resolved and sharp peaks with a tailing factor less than 2 for OFL and ORN. (Figure 2). The retention times of OFL and ORN were $4.278 \mathrm{~min}$ and $6.75 \mathrm{~min}$ respectively. Wavelengths of $295 \mathrm{~nm}$ and $311 \mathrm{~nm}$ were selected as the detection wavelengths for Ofloxacin and Ornidazole respectively. The calibration curve for OFL and ORN was seen to

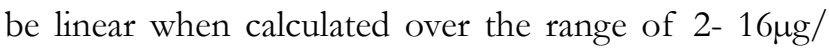
$\mathrm{ml}$. The calibration curves data is shown in Table 1 . The provided method was effectively used on the tablet dosage form to estimate Ofloxacin and Ornidazole. The findings obtained from the combination were equivalent to the corresponding quantities labelled. The method developed was able to distinguish other excipients that are present in the tablet from the two drugs and was therefore found to be specific (Figure 3).

The Limit of Detection for OFL and ORN was estimated to be $0.331 \mu \mathrm{g} / \mathrm{ml}$ and $0.36 \mu \mathrm{g} / \mathrm{ml}$, respectively, while Limit of Quantification was $1.005 \mu \mathrm{g} / \mathrm{ml}$ and $1.092 \mu \mathrm{g} / \mathrm{ml}$, respectively. The validation report and system suitability test parameters report data are presented in Table 2. The

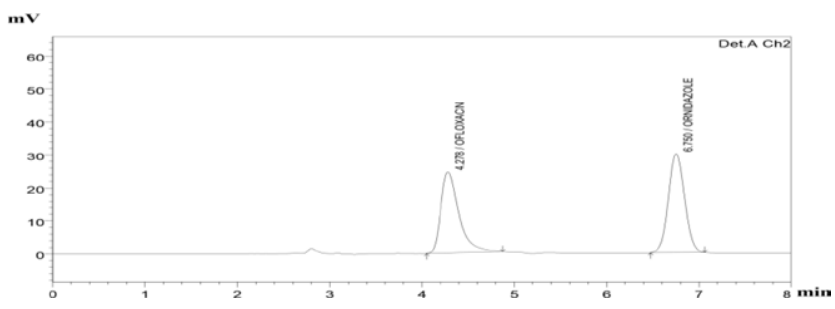

Figure 2: Optimised Chromatogram of OFL and ORN (API mixture).

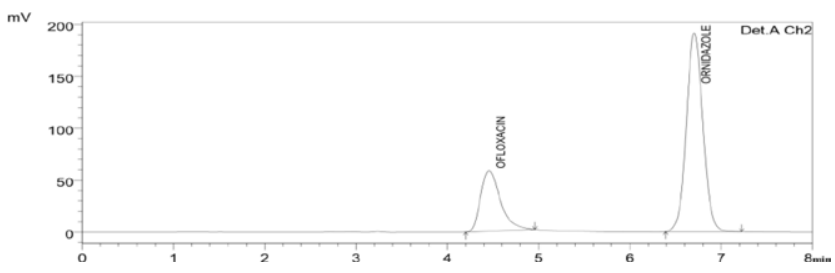

Figure 3: Chromatogram of tablet mixture.

\begin{tabular}{|c|c|c|c|c|}
\hline \multirow{2}{*}{ Sr. No. } & Type of degradation & Stress Conditions & \multicolumn{2}{c|}{$\%$ degradation observed } \\
(\%)
\end{tabular}


summary report of Stress testing of Standard and Tablet are presented in Table 3.

Ofloxacin showed significant photolytic degradation with the generation of excess peaks as Figure 4 but was stable under alkali, acid and oxidative hydrolysis after refluxing at $80^{\circ} \mathrm{C}$ for $8 \mathrm{hr}$ and $80^{\circ} \mathrm{C}$ in the hot air oven for $24 \mathrm{hr}$ (Figures 5-8). Ornidazole was shown to be susceptible to alkali hydrolysis with its peak completely degrading and was also seen to show photolytic degradation as shown in Figures 5 and 7 respectively but was stable under acid and oxidative hydrolysis as well $80^{\circ} \mathrm{C}$ in the hot air oven for $24 \mathrm{hr}$ (Figures 5,7,8).

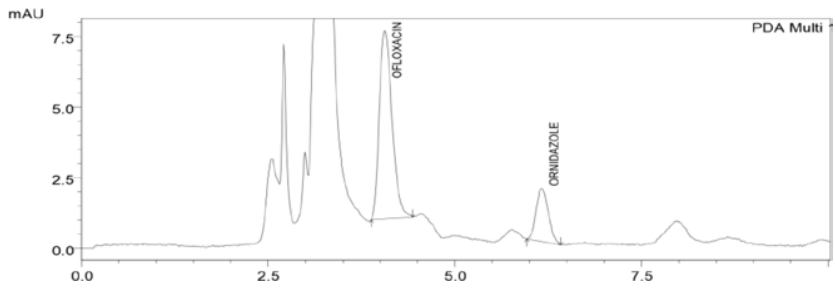

Figure 4: Chromatogram of standard exposed to light after $4 \mathrm{hr}$.

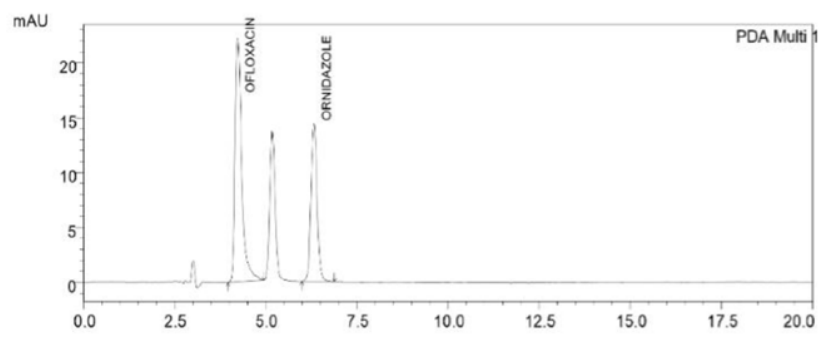

Figure 5: Chromatogram of standard exposed in $0.1 \mathrm{M}$ hydrochloric acid after refluxing for $4 \mathrm{hr}$.
The $\%$ drug delivery was seen to be higher than $80 \%$ in $20 \mathrm{~min}$ for all the evaluated products in case of dissolution studies. The Dissolution observation report for Ofloxacin and Ornidazole is given in Tables 4 and 5

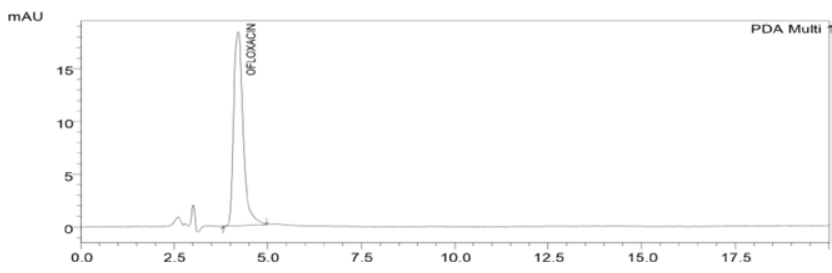

Figure 6: Chromatogram of standard exposed $0.1 \mathrm{M}$ sodium hydroxide after refluxing for $4 \mathrm{hr}$.

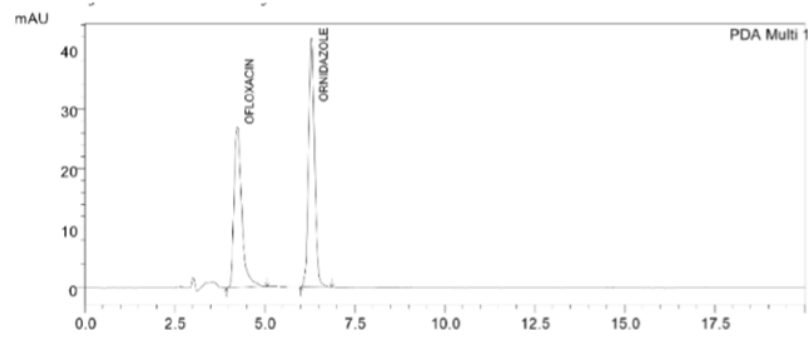

Figure 7: Chromatogram of standard in $30 \% \mathrm{v} / \mathrm{v} \mathrm{H}_{2} \mathrm{O}_{2}$ solution after $4 \mathrm{hr}$.

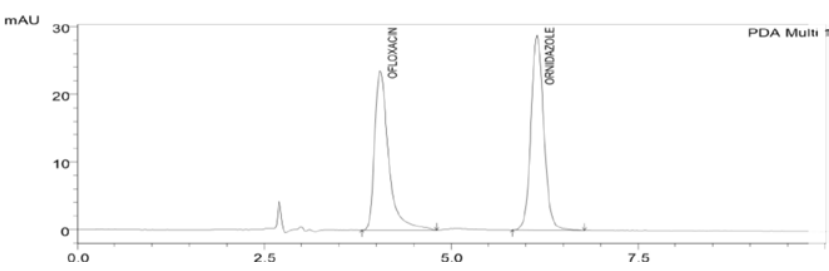

Figure 8: Chromatogram of standard exposed to heat after $24 \mathrm{hr}$.

\begin{tabular}{|c|c|c|c|c|c|c|}
\hline \multicolumn{9}{|c|}{ Table 4: Ofloxacin dissolution observation report } \\
\hline Sr. No & $\begin{array}{c}\text { Time points } \\
(\mathbf{m})\end{array}$ & $\begin{array}{c}\text { Area obtained } \\
\text { (Average of } \mathbf{6} \\
\text { tablets) }\end{array}$ & S.D \pm & \%C.V & $\begin{array}{c}\text { Sample Area/ } \\
\text { Std Area }\end{array}$ & \%Dissolved \\
\hline 1 & 10 & 5754141.33 & 1306153.9 & 22.7 & 2.8 & 25.27 \\
\hline 2 & 20 & 20670005.17 & 1228045.11 & 5.94 & 10.1 & 90.77 \\
\hline 3 & 30 & 22627826 & 224391.47 & 0.99 & 11.01 & 99.37 \\
\hline 4 & 45 & 22182921.67 & 1057278.62 & 4.77 & 10.79 & 97.41 \\
\hline 5 & 60 & 23900745.17 & 1960935.85 & 8.2 & 11.63 & 104.96 \\
\hline
\end{tabular}

\begin{tabular}{|c|c|c|c|c|c|c|}
\hline \multicolumn{7}{|c|}{ Table 5: Ornidazole dissolution observation report. } \\
\hline Sr. No & $\begin{array}{c}\text { Time points } \\
(\mathbf{m})\end{array}$ & $\begin{array}{c}\text { Area obtained } \\
\text { (Average of 6 } \\
\text { tablets) }\end{array}$ & S.D. & \%C.V & $\begin{array}{c}\text { Sample Area/ } \\
\text { Std Area }\end{array}$ & \%Dissolved \\
\hline 1 & 10 & 7178163.17 & 1633624 & 22.76 & 2.83 & 25.63 \\
\hline 2 & 20 & 25040062.3 & 1653505.33 & 6.6 & 9.88 & 89.39 \\
\hline 3 & 30 & 27457169.5 & 286574.57 & 1.04 & 10.84 & 98.02 \\
\hline 4 & 45 & 27633851.5 & 284328.97 & 1.03 & 10.91 & 98.65 \\
\hline 5 & 60 & 27378323 & 2182355.34 & 7.97 & 10.81 & 97.74 \\
\hline
\end{tabular}




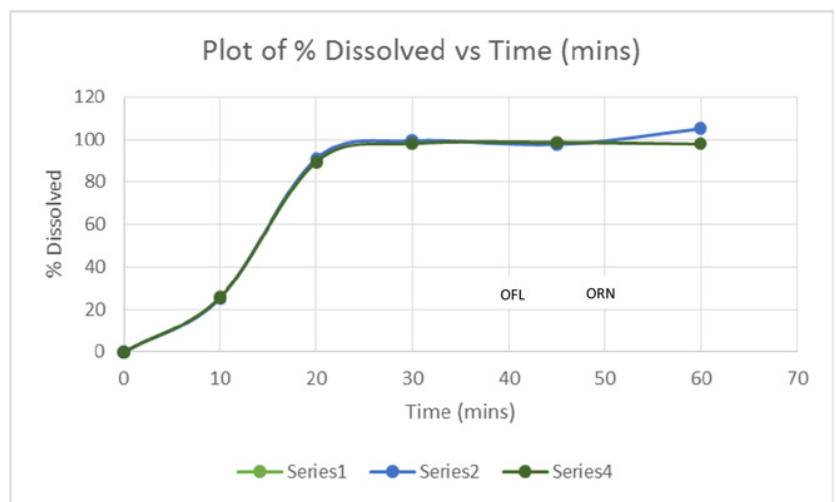

Figure 9: Plot of \% Ofloxacin and Ornidazole dissolved vs time (mins).

respectively and the plot of $\%$ drug dissolved with time is shown in Figure 9.

\section{CONCLUSION}

In the proposed study, a precise, simple, accurate, sensitive and cost effective stability indicating assay method for simultaneous estimation of Ofloxacin and Ornidazole in bulk drug by RP-HPLC was established. The results obtained by analysing the forced degraded samples depicts that there was no other co-eluting peaks of interference due to variable stress components with the main peaks and the method was seen to be specific for the determination of Ofloxacin and Ornidazole amongst various degradants. The method was successfully used for assay and dissolution studies for tablet formulation.

\section{ACKNOWLEDGEMENT}

The authors are grateful to Dr. Ashok Panwar AKUMS Drugs and Pharmaceuticals Ltd, Haridwar (UK) for the supply of the gift samples of both the APIs and the Department of Pharmaceutical Quality Assurance, Manipal College of Pharmaceutical Sciences, Manipal Academy of Higher Education, Manipal for providing the necessary facilities to conduct the research work.

\section{CONFLICT OF INTEREST}

The authors declare that there is no conflict of interest.

\section{ABBREVIATIONS}

mm: Millimeter; nm: Nanometer; L: Liter; ml: milliliter; $\boldsymbol{\mu l}$ : microliter; G: Gram; Mg: milligram; $\boldsymbol{\mu g : ~ m i l l i g r a m ; ~}$ mol: Molarity; mM: millimolar; w/v: weight/ volume; w/w: weight/ weight; v/v: volume/ volume; $\min (\mathrm{s})$ : Minutes; $\lambda$ : Wavelength; $\mu$ : Micron; $\%$ : Percentage; ${ }^{\circ} \mathbf{C}$ : degree Celsius; hr(s): Hours; SD: Standard deviation; RSD: Relative Standard deviation standard deviation; R2: Correlation coefficient; NMT: Not more than; NLT: Not less than; LOD: Limit of detection; LOQ: Limit of quantification; Rt: Retention time; OFL: Ofloxacin; ORN: Ornidazole; TEA: Triethylamine; AR: Analytical grade; $\mathbf{A C N}$ : Acetonitrile; $\mathbf{N H}_{4} \mathbf{C H}_{3} \mathbf{C O}_{2}$ : Ammonium acetate; $\mathbf{N a O H}$ : Sodium hydroxide; $\mathbf{H}_{2} \mathbf{O}_{2}$ : Hydrogen peroxide; ICH: International Council on Harmonization; FDA: Food and Drug Admintration; RP: Reverse Phase; HPLC: High Performance Liquid Chromatography; UV: Ultraviolet; IR: Infrared; PDA: Photo diode array; API: Active Pharmaceutical Ingredients; IUPAC: International Union of Pure and Applied Chemistry; USP: United States Pharmacopoeia; IP: Indian Pharmacopoeia; BP: British Pharmacopoeia; $\mathrm{C}_{18}$ : Octadecyl.

\section{REFERENCES}

1. Dhandapani, Thirumoorthy N. Method development and validation for the simultaneous estimation of ofloxacin and ornidazole in tablet dosage form by rp-hplc. International Journal of Pharma Sciences and Research. 2010;1(1):78-83

2. Nooman AK, Ashok KS, Maher S. Development and validation of an RP-HPLC method for simultaneous analysis of ofloxacin and ornidazole in tablets. Indian Journal of Pharmaceutical Sciences. 2010;3(2).

3. Shaik MY, Vijay KE, Surya SC, Divya E. A New RP-HPLC for Simultaneous Estimation of Ornidazole and Ofloxacin in Bulk and Its Tablet Dosage Form. Asian Journal of research in Chemistry. Available from: http://www. pharmaresearchlibrary.com/a-new-rp-hplc-for-simultaneous-estimation-ofornidazole-and-ofloxacin-in-bulk-and-its-tablet-dosage-form/.Bhusari KD, Chaple DR. Simultaneous spectrophotometric estimation of ofloxacin and ornidazole in tablet dosage form. Asian Journal of research in Chemistry. 2009;2(1):60-2.

4. Saumil M, Sukhdev S. Simultaneous Spectrophotometric Estimation of Ofloxacin and Ornidazole in Tablet Dosage Form. Asian Journal of Research in Chemistry. 2009;2(1):60-2. Available from: https://www.researchgate. net/publication/266347002_Simultaneous_Estimation_of_Ofloxacin_and_ Ornidazole_in_Combined_Dosage_Forms_by_Dual_Wavelength_and_ Ratio_Spectra_Derivative_Methods_using_UV-Spectrophotometer.The Indian Pharmacopoeia Commission, Ghaziabad. Indian Pharmacopoeia. 2018;3:270-1. 
PICTORIAL ABSTRACT

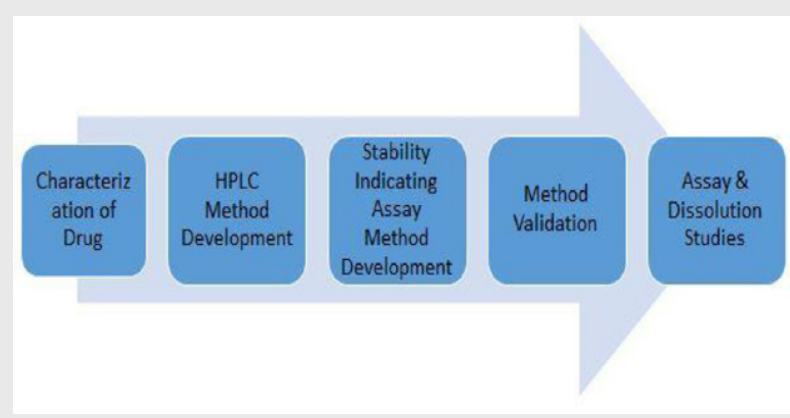

\section{SUMMARY}

A precise, simple, accurate, sensitive and cost effective stability indicating assay method for simultaneous estimation of Ofloxacin and Ornidazole in bulk drug by RP-HPLC was established. The forced degraded sample results were then analysed and it was seen that there was no other co-eluting peaks of interference due to variable stress components with the main peaks and the method was seen to be specific for the determination of Ofloxacin and Ornidazole amongst various degradants. The method was then successfully used for assay and dissolution studies for tablet formulation.

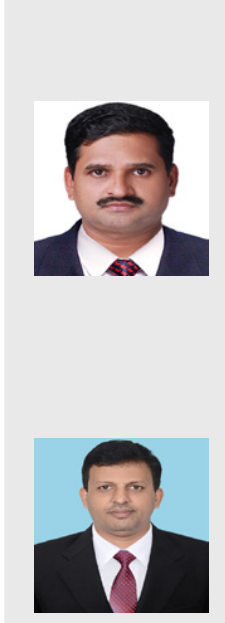

\begin{abstract}
About Authors
Dr. Vasantharaju S G is Associate Professor-Senior Scale in Department of Pharmaceutical Quality Assurance, Manipal College of Pharmaceutical Sciences, Manipal Academy Higher Education and Research. He teaches pharmaceutical analysis to undergraduate students and pharmaceutical quality assurance and management to post graduate students of Pharmacy. He has $25+$ years of total experience in academics, Research \& Development. He has published $60+$ research papers in journals of high repute and have presented papers in national and international conference. Awarded for the best research paper at an APTI convention for the research paper in pharmaceutical Analysis published in IJPER and best presentation at a conference held at Sydney, Australia.
\end{abstract}

Dr. Muddukrishna B.S is Associate Professor in Department of Pharmaceutical Quality Assurance, Manipal College of Pharmaceutical Sciences, Manipal Academy Higher Education and Research. He teaches pharmaceutical analysis to undergraduate students and pharmaceutical quality assurance and management to post graduate students of Pharmacy. He has $20+$ years of total experience in academics, Research \& Development, Laboratory Operations \& Quality Assurance in an organization of high repute. He has published several papers in journals of high repute and have presented papers in national and international conference.

Cite this article: D'Souza K, Syeda A, Khatal P, Muddukrishna BS, Vasantharaju SG. Stability Indicating Assay Method Development and Validation for Simultaneous Estimation of Ofloxacin and Ornidazole by RP-HPLC in Bulk: An Application to Tablet Formulation and Dissolution Studies. Indian J of Pharmaceutical Education and Research. 2021;55(2):607-13. 